\title{
Zahlazení odsouzení do roku 1928 s důrazem na období let 1852-1928
}

\author{
Zdeněk Jiří Skupin
}

Právnická fakulta Masarykovy univerzity

Kontaktníe-mail: 392870@mail.muni.cz

Spent Convictions up to the Year 1928, with Emphasis on Period of the Years 1852-1928

\begin{abstract}
:
The article deals with the development of prison sentences from 1708 to the year 1928 . The term "spent conviction" is related to the deletion of the criminal record or records (it means that the record can be ignored) thus the undermined legal status of the person, who had been convicted, is rehabilitated and restored, which means that no one can blame or remind him or her the crime. It may seem to that the spent conviction is the institution of the modern society but true lies elsewhere. In fact the process of spending conviction and its repercussion appears since 1768, when the substantive law of spent conviction was included in the Constitutio Criminalis Theresiana which was the penal code of empress Marie Theresie. But main progress in the field of spent conviction made Marie Theresie's son Joseph II, whose penal code included extensive provisions on subject matter. Emphasis is placed on penal code about crimes, torts and offences, which came into force in 1852 and had been effective almost for 100 years till 1950 when a new penal code took effect. However, since 1918 the act of redress of conviction become effective, and replaced provisions about spending conviction, which was contained in penal code about crimes, torts and offences. At last, but not least, the act of redress of conviction contained both substantive and procedural law of spent conviction and thus it was the first comprehensive and united act on the subject matter.
\end{abstract}

Key words:

spent conviction; Austro-Hungarian Empire; First Czechoslovak Republic; historical comparison

\section{Klíčová slova:}

zahlazení odsouzení; Rakousko-Uhersko; první republika; historická komparace

DOI: $10.14712 / 2464689 X .2018 .46$

Financování: Příspěvek vznikl v rámci projektu Recentní překážky efektivního naplňování cílů trestního řízení, MUNI/A/1143/2017. 
Zahlazení odsouzení lze považovat za jeden z institutů vycházejících ze základů současné demokratické společnosti. Zejména je důležité vyzvednout jeho spojení se zásadou subsidiarity trestní represe a z ní vycházejícího principu ultima ratio, který se z hlediska viny promítá do trestního práva, zjednodušeně řečeno tak, že přednostně by mělo být užito prostředků ochrany jiných právních odvětví a prostředků trestního práva by mělo být užito až subsidiárně, tj. v př́ípadě, kdy je ochrana těmito odvětvími nedostatečná. $Z$ hlediska trestání trestat jen $\mathrm{v}$ nejnutnější míře a dávat přednost mírnějším trestům před tresty přísnějšími, což koresponduje s myšlenkami zahlazení odsouzení, nebot' skrze zahlazení dochází k vyjádření „uspokojení“ společnosti nad potrestáním pachatele, př́íp. ztrátě zájmu společnosti na potrestání pachatele, ${ }^{1}$ což vede ke skutečnosti, že odsouzeného již dále není třeba trestat ani jinak omezovat, např. ve výkonu povolání nebo jiných činností.

Zahlazení je bezpochyby spojeno se současnými vývojovými trendy, tj. s restorativní justicí, avšak za předpokladu zachování justice retributivní. Restorativní účinek lze spatřovat, jak bylo výše naznačeno, v zániku negativních důsledků odsouzení („odstranění“, lépe řečeno neuvedení, záznamů o trestném činu ve výpisu z rejstř́iku trestů) ve vztahu $\mathrm{k}$ širší veřejnosti a většině státních orgánů. S tím jsou spojeny důsledky zániku recidivy v právním smyslu² (jak omezené, tak neomezené), a již zmiňované důsledky neobsažení zahlazených odsouzení ve výpisu z evidence rejstř́ku trestů. Na druhou stranu, retributivní prvky lze spatřovat v zachování zákonem stanovené doby, po niž musí odsouzený vést řádný život, je tudíž pod drobnohledem státu, což má důsledky spočívající zejména v možnosti soudu hodnotit dosud nezahlazené odsouzení jako zmiňovanou recidivu, tj. soud přičítá recidivu bud' (obligatorně) jako zvláště přitěžující okolnost nebo (fakultativně) jako okolnost obecně přitěžující (s přihlédnutím k zásadě ne bis in idem). Retributivní prvky lze spatřovat i u zahlazených odsouzení, nebot' k těmto mají př́stup zákonem stanovené státní orgány, které tyto informace využívají k hodnocení osoby pachatele, př́ikladem za všechny je napřs. soud při obecném ukládání trestů ${ }^{3}$ nebo orgán státní správy myslivosti při ustanovování myslivecké stráže. ${ }^{4}$

Lze tak nabýt dojmu, že zahlazení odsouzení je trendem současné doby, opak je však pravdou. S podobou zahlazení odsouzení stricto sensu $u^{5}$ se lze totiž setkat již v osvícen-

1 Např. promlčením, nebo skrze rozhodnutí prezidenta republiky (milosti nebo amnestie).

2 Srov. KUCHTA, J. In: KRATOCHVÍL, V. Trestní právo hmotné: obecná část. 2. vyd. Praha: C. H. Beck, 2012, s. 405-408.

3 §39 zákona č. 40/2009 Sb., trestní zákoník, ve znění pozdějších předpisů (dále jen „trestní zákoník“).

4 Srov. zákon č. 449/2001 Sb., o myslivosti, ve znění pozdějších předpisů.

5 Při pohledu na koncepci zahlazení v historických pramenech a na institut zahlazení odsouzení v současné úpravě trestního zákoníku lze rozlišit zahlazení odsouzení na zahlazení odsouzení lato sensu a zahlazení odsouzení stricto sensu. Zahlazení odsouzení lato sensu vychází z historického chápání, kdy lze říci, že zahlazení (shlazení) bylo považováno za obecnější zánik negativních důsledků odsouzení (srov. níže v jednotlivých kapitolách) spojeného s fikcí neodsouzení, kdežto zahlazení odsouzení stricto sensu vychází z dnešního, relativně úzkého, pojetí institutu upraveného v $\$ 105$ a $§ 106$ trestního zákoníku. Toto pojetí nesmí být slučováno s důsledky, k nimž vede, tj. s důsledky, že se na pachatele hledí, jako by nebyl odsouzen, nebot' $\mathrm{k}$ fikci neodsouzení lze dospět i jinými instituty a to např. osvědčením se ve zkušební době, milostí nebo amnestií prezidenta republiky, a slučovat tyto instituty na základě stejných důsledků by bylo chybné. Nebezpečí sloučení je možné připodobnit ke sloučení institutů krajní nouze a nutné obrany, a to jen $\mathrm{z}$ důvodu, že oba instituty vedou $\mathrm{k}$ vyloučení protiprávnosti, tento myšlenkový postup je proto nesprávný. $\mathrm{Z}$ tohoto důvodu není možné osvědčení se ve zkušební době, milost nebo amnestii prezidenta republiky slučovat a podřazovat pod zahlazení stricto sensu, avšak tato skutečnost nebrání považovat všechny zmíněné za (historické) pojetí zahlazení lato sensu. 
ství, ${ }^{6}$ avšak je možno předpokládat, že se zahlazení odsouzení lato sensu uplatňovalo již v dobách dřívějších, např. pravomocí panovníka udělovat milosti.

Článek se věnuje analýze vývoje institutu zahlazení od roku 1708, resp. od roku 1768, kdy lze v kodifikovaných předpisech zaznamenat jistou obdobu, př́padně podobu zahlazení odsouzení, tak jak ji chápeme v dnešní době (tj. zahlazení odsouzení stricto sensu). Důraz je kladen na období od roku 1852 do roku 1918, kdy pro oblast odčinění odsouzení byl platný a účinný trestní zákoník o zločinech, přečinech a přestupcích, a na období od roku 1918 do roku 1928, kdy byl platný a účinný zákon o odčinění odsouzení. Článek se zaměřuje na analýzu právní podoby zahlazení odsouzení v Rakouském později Rakousko-Uherském mocnářství ${ }^{7}$ (konkrétně na jeho Předlitavskou část) a její komparaci se současnou právní úpravou.

\section{Zahlazení odsouzení v letech 1708-1852}

Constitutio criminalis Josephina ${ }^{8}$ z roku 1708 byl převážně předpisem procesněprávním, a tudíž ustanovení o jakékoliv podobě, př́ípadně variantě zahlazení odsouzení neobsahoval. Důvodem této skutečnosti bylo, že Constitutio criminalis Josephina byl předpisem subsidiárním, primárními zdroji byly zejm. Koldínův zákoník ${ }^{9}$ a Obnovené zřízení zemské, ${ }^{10}$ avšak ani tyto předpisy explicitně neobsahovaly ustanovení o zahlazení odsouzení. Na druhou stranu Constitutio Criminalis Theresiana ${ }^{11}$ z roku 1768 již obsahoval explicitně vtělená ustanovení o zahlazení odsouzení, tuto skutečnost spojoval např. s promlčením trestní odpovědnosti za přečinění, kdy toto bylo spojováno se „zhlazením a uhasnutím“, tj. přečinění nesmělo být nikomu vyčítáno, a to ani při dalším trestním stíhání za jiné přečinění. ${ }^{12}$ Nemožnost zahlazení některých trestů vyplývala z jejich povahy, typicky jimi byly napřr. tělesné tresty v podobě vypálení cejchu (trestního znamení). ${ }^{13}$

S ,vyšším stupněm“ zahlazení, které má již jednotnou a ucelenou formu, se lze taktéž setkat v trestním zákonu Josefa II. z roku 1787, který nesl český název: „Práwa wffeobecná

6 Srov. níže jednotlivé kapitoly.

7 Zákon č. 108/1918 ř. z., o odčinění odsouzení nabyl platnosti a účinnosti za trvání Rakousko-Uherského mocnářství (ač na jeho sklonku) a byl účinný až do roku 1928, proto je do článku zařazeno i toto období, přestože svou účinností spadá převážně do období První republiky.

8 Constitutio Criminalis Josephina (Geho Milosti ržimského cýsaře, vherského a cžeského krále, ec. Jozeffa Prwnjho. Arcy-knjžete Rakauského, ec. pána nasseho negmilostiwěgssýho. Nowé práwo vtrpné a hrdelnj, pro králowstwj Cžeské, margrabstwj Morawské a knjžetcstwj Sleské. Anno M. DCC. VIII., Nákladem podle cýsařského neymilostiwěgssýho nadánj Kasspara Jana Kupce z Bilenbergku. V dědičůw Jana Karla Geřábka, 1703. Dostupné na: https://books.google.cz/books?id=wh5fAAAAcAAJ\&printsec=frontcover \&redir_esc $=\mathrm{y} \# \mathrm{v}=$ onepage $\& \mathrm{q} \& \mathrm{f}=$ false.

9 MALÝ, K. Práva městská Království českého: edice s komentářem. Vyd. 1. Praha: Karolinum, 2013. Srov. též KRISTIÁN Z KOLDÍNA, P. - JIREČEK, J. (ed.). Práva městská království českého a markrabství moravského: spolu s krátkou jich summou. Vyd. 5. Praha: Všehrd, 1876, (dále jen „Práva městská“).

10 JIREČEK, H. Obnovené Právo a Zř́zeni Zemské dédičného království Českého. Praha: Nákladem F. Tempského, 1888. Dostupné také na: https://digi.law.muni.cz/handle/digilaw/201 (dále jen „Obnovené zř́zení zemské").

11 Constitutio Criminalis Theresiana aneb Ržjmské Cýsařské w Vhřjch a Vžeskách etc. etc. Králowské Aposstolské Milosti Marye Terezye Arcy-Kněžny Rakauské etc., etc. hrdelnj Práwnj Ržád, W Wjdni: Wytisstěný v Jana Tomasse vrozeného z Trattnerů, Cýsařsko-Královského Dworského Impressora, 1769.

12 Tamtéž, Art. $16 \S 5$.

13 Tamtéž, Art. 6. 
nad Prowiněnjmi, a yích Treft'mi“ (Práva všeobecná nad proviněními a jich trestmi). ${ }^{14}$ Takto je možno usuzovat z $§ 182$, který uváděl, že: „Zločin, neb prowiněnj za zmazané, a zruffené fe drží, když zločinec, neb prowinitel Trest fobě ofauzený wyftál“", ${ }^{15}$ ve spojení s § 184, který uváděl: „Když Zločin, neb Prowinění, Trestanliwoft Trestem wystálým, anebo Miloftí Udělenjm fe zmazala, a minula, tedy Zločinec, neb Prowinnitel někdeyffi od Zločinu, a Prowiněnj fwého za zauplna očiftěného patřijn býti má, a do wffech fpolečných měfsfkých Práw opět wftupuye, potudž zráta yich fnád Máfkedet, neb Djl wýffowný Ortele treftmjho nebyl. Pročež w Pžíwánj těchž od nikoho zaměfttnáwán, zaneprazdňowán, neb fužován; též potudž Žiwot, a Obcowánj fwé budaucý beztreftně, a práwně powede, yemu od někoho co Předefflého wytýkáno, a předhazováno, aneb on z Strany toho Způsobem yakýmkoli od nikoho tupen, haněn, neb uražen býti nemá."16 Výkon trestu tak byl spojován s obnovou všech společných městských práv. Zejména je podstatná poslední věta $\S 184$, jelikož uvádí, že pro případy, kdy odsouzený trest vykonal nebo mu byl prominut, mu př́slušné odsouzení nesmí jít jakkoli k úhoně, zejména mu nesmí být vytýkáno, nesmí být haněn nebo urážen. Samozřejmě je nutno dodat, že jak ustanovení $\S 182$, tak ustanovení $\S 184$ měla působnost na všechny obyvatele říše, bez rozdílu jejich stavu nebo původu. ${ }^{17}$ Tímto způsobem byla vyjádřena myšlenka současného pojímání zahlazení odsouzení. V porovnání s recentní úpravou lze říci, že v současnosti je možné zahladit jakýkoliv uložený trest, tj. i výjimečný trest na doživotí, ${ }^{18}$ důležitou skutečností je i neexistence tělesných trestů, případně trestů s trvalým následkem. ${ }^{19}$

Navazujícím zákonem byl zákoník o zločinech a těžkých policejních přestupcích ${ }^{20} \mathrm{z}$ roku 1803 císaře Františka II. Dobová forma zahlazení se nacházela v ustanoveních § 201-210, hlavě osmnácté „O zacházení a přestáwání zločinůw a trestůw“. Mezi skutečnosti zajití a přestání zločinu náležela smrt pachatele, vystátí ${ }^{21}$ trestu, opomenutí téhož a zletilostí neboli zajitím let právních. Tento zákon se s vystátím trestu vypořádává velmi obdobně jako zákon předchozí. Pro případy, že odsouzený zločin vystál, vstupoval zpět do všech společ-

14 Allgemeines Gesetz über Verbrechen, und derselben Bestrafung: Wird verkauft ungebunden das Stück auf Schreibpapier für 12.kr. gebunden für 18. kr. auf Druckpapier für 8. kr. gebunden für 14. kr. Wien: Gedruckt bey Johann Thomas Edlen von Trattner, k. k. Hofbuchdrucker und Buchhändler, 1787.

15 Tamtéž, $\$ 182$ (pozn. přepis ze švabachu). Ve stručnosti lze ustanovení parafrázovat: „Pokud zločinec (provinitel) trest vystál, má se za to, že je zločin (provinění) smazán a zrušen.“

16 Tamtéž, § 184 (pozn. přepis ze švabachu). Ve stručnosti lze ustanovení parafrázovat: „Došlo-li k zániku trestu na základě vystátí či udělenou milostí, má se za to, že zločinec (provinitel) je zcela očištěn od takovéhoto zločinu (provinění), znovu vstupuje do všech svých práv městských, potud pokud nad odsouzeným nebyl vyřknut výslovný trestní ortel. Pokud odsouzený poté vede beztrestný život, nesmí mu býti vytýkáno a připomínáno jeho předchozí odsouzení, stejně tak nesmí být jakýmkoliv způsobem za předchozí odsouzení tupen, haněn nebo urážen.“

17 Srov. první překlad obecného zákoníku občanského, který hovoří o všech zákonech městských.

18 Samozřejmě za splnění dalších zákonem stanovených podmínek v případě, že je odsouzený podmíněně propuštěn z výkonu trestu odnětí svobody na doživotí.

19 Nic ovšem nebrání zákonodárci, aby provedl legislativní zásahy a recentní úpravu změnil tak, že některé, kupř. nejzávažnější zločiny, nebude možno zahladit. V této věci je důležitá otázka odůvodněnosti takové změny, zejm. poté rozpor se základními zásadami trestního práva, resp. ústavními hodnotami a právy.

20 Jungmann VI.1678. Doucha 309. Riegrův sl. nauč. X. 383 (Kniha práv nad preč́iněními hrdelními. We Wídni: Jana Tomáše Urozeného z Trattnerův, 1804.)

21 Dobové předpisy pro soudobý pojem ,,výkon trestu“ používaly pojmu „,vystátí trestu“. Pojmy lze používat promiscue, avšak autor se v zde a v dále v textu přidržuje pojmů tak, jak byly použivány v předpisech, které byly účinné a platné ve zkoumaném období. 
ných městských práv, výjimku tvořily př́ipady, kdy byla ztráta bezúhonnosti následkem rozsudku. S vystátím zločinu byly také spojovány následky „zahlazení“, nebot' odsouzenému neměl být zločin dále vytýkán a „předhazován“, neměl být za něj „,tupen, haněn nebo urážen“. Stejné účinky jako „vystátí“ zločinu mělo jeho odpuštění (opomenutí zločinu).

$\mathrm{Na}$ tomto místě je vhodné připomenout, že všechna odsouzení byla zahlazována ex lege, tj. automaticky, nastala-li výše zmíněná skutečnost, v recentní úpravě se lze setkat se zahlazením ex lege pouze u některých alternativních trestů, ${ }^{22} \mathrm{v}$ ostatních prípadech je zahlazováno ex decreto ( $\mathrm{k}$ této skutečnosti je tak třeba rozhodnutí soudu).

Důležitou skutečností, týkající se výslovného vložení slov zákazu tupění, hanění, urážení atd., bylo pojetí cti ve stavovské společnosti. Čest osoby byla nepostradatelnou součástí jak právního, tak společenského života již od dob římské společnosti, kdy infamia (nečestnost) byla důvodem omezení způsobilosti k právnímu jednání, ${ }^{23}$ svůj význam si zachovala dlouhou dobu; od 19. století již infamia není spojována s omezením právní způsobilosti. ${ }^{24}$ Právní (ne)způsobilost nebyla jediným důsledkem infamie, mezi další lze zařadit např. zákaz podání svědecké výpovědi, ${ }^{25}$ zákaz manželství s dcerami lidí dobře zachovalých, tak stejně zákaz osvojení sirotků, těchto osob ${ }^{26}$ atd. Důsledkem zahlazení tak bylo (znovu) nabytí cti a s tím spojených dalších práv.

Recentní právní úprava zaznamenala výrazný posun významu cti, resp. její ztráty a dopadů do právního života, avšak lze říci, že význam ve společenském životě zůstal zachován, zahlazení tak nemá vliv na čest a integritu ve společenském životě, odsouzený nabývá ,pouze“ bezúhonnost soudní. ${ }^{27}$

Pro shrnutí, období od roku 1708-1852 se vyznačovalo následujícím: 1. Objevovaly se první náznaky zahlazení odsouzení, a to již v relativně př́ísném trestním předpisu Constitutio Criminalis Theresiana. 2. Zahlazovalo se ex lege vystátím trestu, milostí, později též smrtí pachatele a promlčením. 3. Zahlazena nemohla být odsouzení spočívající v trestu cejchu nebo jiné značky. 4. Zahlazení odsouzení bylo spojeno s obnovou městských práv, resp. všech práv (vyjma vyslovení ortele). 5. Zahlazením byly spojeny účinky zákazu přihlížení k odsouzení a zákazu připomínání odsouzení pachateli, včetně jakýchkoli jiných negativních důsledků (obnova cti).

\section{Zahlazení odsouzení v letech 1852-1918}

Zákon č. 117/1852 ř. z., jímžto se vyhlašuje, a počínajíc od 1. září 1852, ve skutek uvádí nové, pozdějšími zákony doplněné, více novými ustanoveními rozmnožené vydání zákonníka trestního o zločinech a těžkých policejních přestupcích od 3. záři 1803, jakožto jediný zákon trestní o zločinech, přečinech a přestupcích pro celou říši, vyjímajíc Hranici

22 Trest obecně prospěšných prací, trest zákazu činnosti, peněžitý trest uložený za přečin spáchaný z nedbalosti a v př́ipadě, kdy není uložen trest a je tudíž upuštěno od potrestání.

23 SKŘEJPEK, M. Řimské soukromé právo: systém a instituce. 2. upravené vydání. Plzeň: Vydavatelství a nakladatelství Aleš Čeněk, 2016, s. 55.

24 VOJÁČEK, L. Urážky, pomluvy, nactiutrhání: ochrana cti v československém trestním právu. Praha: Eurolex Bohemia, 2006, s. 9.

25 JIREČEK, Obnovené Právo, Čl. D. XIII.

26 MALÝ, c. d., Ц̆l. M. XLII.

27 Zmíněné lze demonstrovat na př́kladu, kdy osoba A prohlásí o osobě B, že tato byla odsouzena pro trestný čin, ač toto odsouzení bylo již zahlazeno. Osoba A se neopouští trestného činu, nebot' neprohlásila lživou (nepravdivou) informaci o osobě B, přestože by jinak zdánlivě byly naplněny znaky skutkové podstaty pomluvy (§ 184 trestního zákoníku). 
vojenskou (dále jen „Zákon o zločinech, přečinech a přestupcích“), navazoval výraznou měrou na svého předchůdce, Zákoník o zločinech a těžkých policejních přestupcích.

Zákon o zločinech, přečinech a přestupcích byl rozdělen do dvou hlavních částí, první z nich byla zaměřena na problematiku zločinů, druhá poté na přečiny a přestupky. Zákon byl nastaven relativně přísně, nebot' s rozsudkem o vině a vysloveném trestu byly spojeny i další účinky (mimo samotnou povinnost podvolit se trestu). Tyto účinky konkrétně vyjmenovával $§ 26$ zákona o zločinech, přečinech a přestupcích. „S každým odsouzením pro zločin jsou mocí zákona spojeni tito účinkové: a) odejmutí všelikých řádů tuzemských i cizozemských, čestných znamení civilních i vojenských; b) ztráta všelikých veřejných titulů i akademických stupňů a hodností, a odejmutí práva, nabyti jich znovu neb zase bez povolení Císařova; ... d) ztráta všelikého úřadu veřejného nebo všeliké služby veřejné, zahrnujíc v to i úřad učitelský, a nespůsobilost', dosáhnouti jich znovu neb zase bez výslovného povolení Císařova...", mezi další účinky zákon řadil např. ztrátu způsobilosti být soudcem, advokátem, notářem, ztrátu práva na penzi nebo jiné př́íspěvky atd. ${ }^{28}$

Tímto ustanovením nebyla dotčena jednotlivá ustanovení občanských, politických a církevních předpisů. Což v období První republiky ${ }^{29}$ znamenalo, že pokud s odsouzením za zločin př́íslušné předpisy spojovaly další škodlivý (nepříznivý následek) pro pachatele, tento byl k trestu ,přičten“. Mezi tato omezení náleželo např. omezení nabytí československého státního občanství cizincem, ${ }^{30}$ nezpůsobilost $\mathrm{k}$ přísežnému výslechu svědeckému, ${ }^{31}$ vyloučení ze zápisu do stálých seznamů voličských ${ }^{32}$ atd.

V obdobném smyslu se neslo i ustanovení následující, 33 které spojovalo s odsouzením $\mathrm{k}$ trestu těžkého žaláře, př́íp. trestu smrti, v písm. a) zánik (ztrátu) šlechtického titulu odsouzeného (ale pouze ve vztahu ke své osobě, tj. osobě odsouzené), za předpokladu, že byl šlechticem. Druhým účinkem, v písm. b), byl ten, že v průběhu vykonávání trestu nemohl odsouzený právně jednat, konkrétně se právně zavazovat nebo také pořizovat pro př́pad smrti, tím ale nebyla vyloučena platnost takových jednání před spácháním zločinu.

Recentní úprava zaznamenala výrazný posun, nebot' je nutno šetřit jak osoby poškozené, tak osoby pachatele v duchu zásady humanismu a humanity trestání, proto jsou vyloučeny kruté, nelidské a prrísné tresty. S tímto jsou spojena i př́padná omezení pachatele, kdy jako jeden z největších zásahů do základních práv je považováno odnětí osobní svobody a s tím spojených práv (pohyb, pobyt, aj.), avšak nedochází k omezení dalších práv, typicky zejm. není nikterak dotčena způsobilost odsouzeného. Na druhou stranu i v současnosti s odsouzením (ztrátou soudní bezúhonnosti) jsou spojována omezení spočívající např. v nemožnosti nabýt určitá povolání, ${ }^{34}$ u nichž je třeba zvýšené společenské integrity, mravnosti, cti aj.

$28 \S 26$ zákona o zločinech, přečinech a přestupcích.

29 Srov. KALLAB, J. - HERRNRITT, V. Trestni zákony československé platné v Čechách, na Moravě a ve Slezsku. Praha: Nákladem Československého Kompasu, 1923, s. 30.

$30 \S 29 \mathrm{ABGB}$.

31 §336 zákona č. 113/1895 ř. z., o soudním řízení v občanských rozepřích právních (civilní řád soudní) ve znění př̀dpisů jej měnících a doplňujících do dne 31. 12. 1947.

$32 \S 3$ zákona č. $663 / 1919 \mathrm{Sb}$. z. a n.

33 Tamtéž, $\$ 27$.

34 Mezi typická povolání náleží napřr. soudci (z. č. 6/2002 Sb.), advokáti (z. č. 85/1996 Sb.), státní zástupci (z. č. 283/1993 Sb.), a dále výkon živnosti (z. č. 455/1991 Sb.), byl-li trestný čin spáchán při výkonu této činnosti apod. 
Velkou přísnost lze sledovat v ustanovení $§ 26 \mathrm{v}$ prrípadech písmen b) a d), kdy účinek odsouzení byl spojen s nemožností znovunabytí př́slušných vyznamenání, titulů, úřadů atd., tedy s přetrváním účinku potrestání za zločin, s výjimkou dispensu samotným císařem.

Jistá forma institutu zahlazení se nacházela na konci dílu o zločinech, v ustanoveních o pomíjení zločinů a trestů. Mezi skutečnosti pomíjení zločinu (v současné terminologii by se příslušná ustanovení dala vyložit jako kombinace okolností způsobujících zánik trestní odpovědnosti a okolností způsobujících zánik trestu, nebot' splňují podmínky kvalifikace obou kategorií) byly řazeny: smrt zločince, vystátí trestu, prominutí trestu a promlčení.

Quasi funkci zahlazení mělo promlčení, nebot' se promlčoval pouze spáchaný zločin, tudíž pachatel nemohl být za tento odsouzen, a tím mu nevznikal žádný nepříznivý následek. Společně s promlčením zákon upravoval jeho podmínky, délku promlčecí doby a její počítání nebo vyloučení z promlčení. Na rozdíl od toho, prominutí trestu již v sobě snoubilo funkci zahlazení odsouzení zcela, nebot' se př́íslušné ustanovení svými účinky odkazovalo na účinky vystátého trestu.

Pravým zahlazením trestu (tak, jak jej chápeme dnes) byla okolnost, jíž se trest vystál. Všechny zločiny se tak, slovy zákona, „,shlazovaly“ ex lege na základě jejich výkonu. Odsouzený pachatel poté nabyl všech společenských občanských práv, na nichž byl na základě odsouzení omezen, příp. jichž byl zbaven. To však neplatilo pro případy, které vyjmenovával § $25-27$ zákona o zločinech, přečinech a přestupcích, tedy pro prrípady, ztratil-li pachatel na základě odsouzení práci ve veřejném úřadu, tuto automaticky nezískával zahlazením zpět. Otázka, která vyvstává s touto výjimkou znovunabytí občanských práv, je spojena s tím, zda zanikala i skutečnost nemožnosti znovunabytí ztracených titulů a úřadu, jak je uvedeno v písm. b) a d) $§ 26$ zákona o zločinech, přečinech a přestupcích, bez císařova dispensu. Přestože věta druhá a třetí $§ 225$ zákona o zločinech, přečinech a přestupcích, konkrétně zmiňuje: „A protož nemůže jemu nikdo v požívání práv takových překážeti, ani př́ikoří činiti. Také nemá, pokud počestný život vede, tím, co již minulo, od nikoho dotýkán, aniž má proto jakýmkoli spůsobem haněn býti“',35 čímž je vyjádřena myšlenka zahlazení, ve smyslu toho, že odsouzená osoba se stala znovu bezúhonnou, nelze říci, že s tím zanikala nemožnost znovu nabýt prŕislušné vymezené tituly a úřady. Tato skutečnost vyplývá z toho, že jak $§ 26$, tak $§ 225$ jsou obecná ustanovení o trestání, resp. zániku trestů a neexistuje mezi nimi vztah subsidiarity a speciality. Zároveň $\S 225$ se pro př́pad „shlazení“ zmiňuje pouze o obnově všech práv občanských, tj. obnově práv obsažených v $\S 61,{ }^{36} \S 574,{ }^{37} \S 868^{38}$ a $§ 191,{ }^{39} \S 254,{ }^{40} \S 281^{41}$ zákona č. 946/1811 Sb. z. justičních,

$35 \S 225$ zákona o zločinech, přečinech a přestupcích.

36 „Zločinec odsouzený k trestu nejtěžšího nebo tě̌̌kého žaláře nemůže ode dne, kterého mu byl rozsudek ohlášen a po dobu jeho trestu vstoupiti v platné manželství.“

37 „Zločinec, který byl odsouzen k trestu smrti, nemůže ode dne ohlášeného mu rozsudku, byl-li však odsouzen k trestu nejtěžšího nebo těžkého žaláře, pokud jeho trest trvá, učiniti platné prohlášení poslední vůle.“

38 „Pokud zločinec může sjednávati platné smlouvy, ustanovuje trestní zákon o zločinech.“

39 „Nezpůsobilými k poručenství vůbec jsou ti, kdož nejsou s to pro svoji nezletilost, tělesné nebo duševní vady nebo z jiných př́ičin obstarávati své vlastní věci; kdož byli uznáni vinnými zločinem nebo od nichž nelze očekávati řádnou výchovu sirotka nebo užitečnou správu jmění.“”

40 „Poručník musí býti z úřední moci propuštěn, spravuje-li poručenství proti svým povinnostem, ukáže-li se neschopným nebo vyjdou-li stran něho najevo takové okolnosti, které by jej po zákonu vylučovaly z převzetí poručenství.“

41 „Kdo má př́slušné vlastnosti pro poručenský úřad, může také převzíti opatrovnictví. Př̆i opatrovnictví mají též místo stejné omluvné důvody a přednostní práva jako při poručenství.“ 
obecný zákoník občanský (dále jen „ABGB“), nikoliv již o obnově možnosti znovu nabytí ztracených titulů a úřadů. Nezbytné je také zohlednit novelu zákona o zločinech, přečinech a přestupcích (o ní dále). Proto je nutno uzavřít, že jednou ztracené tituly, vyznamenání a úřady již bez císařova dispensu nebylo možno vůbec nabýt, a to ani pro futuro.

Významnou novelu přinesl zákon č. 131/1867 ř. z., kterým se mění některá ustanovení obecního trestního zákoníku a jiná s ním související nařízení. Tento zákon zrušil omezení obecných občanských práv plynoucí z $§ 27$ písm. b) ${ }^{42}$ zákona o zločinech, přečinech a přestupcích. Posunu také dostála ustanovení o ztrátě titulů, vyznamenání a úřadů, u vymezených trestných činů totiž nezpůsobilost jejich nabytí zanikla s koncem trestu, $\mathrm{v}$ prrípadě nevyjmenovaných trestných činů nezpo̊sobilost nabytí zanikla uplynutím doby deseti, pěti nebo tř́ let, dle výměry trestu žaláře, od vykonání uloženého trestu. Tato skutečnost neznamenala, že ten, kdo o př́slušný titul nebo vyznamenání přišel, jej opět automaticky nabyl, odpadla pouze překážka titul nabýt do budoucnosti.

Současný trest ztráty čestných titulů nebo vyznamenání je možné uložit pouze vedle nepodmíněného trestu odnětí svobody, ${ }^{43}$ avšak doba výkonu nepodmíněného trestu odnětí svobody nezakládá překážku znovunabytí příslušného titulu nebo vyznamenání. Zmíněný trest se vztahuje pouze na čestné tituly a vyznamenání, odsouzený tak neztrácí např̀. „běžné" akademické tituly.

Za zmínku poté stojí úprava pomíjení přečinů a přestupků a trestů za ně ukládaných, uvedená v dílu druhém předmětného zákona, která vycházela s drobnými úpravami (zejména v oblasti snížení dob ${ }^{44}$ a jiných požadavkư ${ }^{45}$ ) z úpravy pomíjení zločinů. Výkon trestu, obdobně tak prominutí trestu, který byl uložen za přečin nebo přestupek, měl stejný účinek jako vystálý trest.

Ve srovnání se současnou úpravou lze vyslovit názor, že úprava zahlazení v době Rakouska-Uherska byla $\mathrm{z}$ jednoho pohledu mírnější, pro případy zahlazení všech trestných činů ex lege po jejich výkonu, z druhého pohledu výrazně přísnější, pro případy absolutní nemožnosti nabýt ztracené tituly, vyznamenání nebo úřady (před novelou). Příslušná novela stanovila zkušební dobu pro možnost nabytí titulů, vyznamenání nebo úřadů, a tím se výrazným způsobem přiblížila současné úpravě s tím rozdílem, že ztráta čestných titulů nebo vyznamenání je v současném trestním zákoníku upravena jakožto samostatný trest ${ }^{46}$ $\mathrm{s}$ relativně přísnými podmínkami, které musí být splněny, aby mohl být uložen. Kdežto zákon o zločinech, přečinech a přestupcích spojoval ztrátu těchto titulů a vyznamenání automaticky s odsouzením za zločin.

S nadsázkou lze říci, že tato úprava působila obdobným způsobem, jako např́iklad dnešní přikládání výpisu z rejstříku trestů u prrihlášek k výběrovému rrízení do veřejných úřadů, u nichž je žádána bezúhonnost, nebot' trest byl zahlazen automaticky jeho výkonem, avšak zůstal zákaz výkonu veřejných úřadů po určitou dobu od vykonání trestu.

Pro shrnutí, období od roku 1852-1918 se vyznačovalo následujícím: 1. Zákon o zločinech, přečinech a přestupcích již řádně užíval pojmu „shlazení“ odsouzení. 2. Odsouzení se shlazovalo smrtí zločince, vystátím trestu, prominutím trestu a promlčením. 3. Novela

\footnotetext{
42 Ustanovení omezující právní jednání v oblasti občanského práva a pořízení pro případ smrti.

$43 \quad$ Srov. $§ 78$ trestního zákoníku.

44 Viz jaký čas promlčení jest u přečinů a přestupků $§ 532$ zákona o zločinech, přečinech a přestupcích.

45 Viz vyloučení z promlčení § 531 zákona o zločinech, přečinech a přestupcích.

$46 \quad$ Srov. $§ 78$ trestního zákoníku.
} 
z roku 1867 přinesla velké změny, umožnila znovu nabýt ztracených titulů, vyznamenání a úřadů, odsouzení nebylo spojeno s omezením občanských práv (na rozdíl od období před novelou). 4. Pro délku nezpůsobilosti nabýt ztracených titulů, vyznamenání a úřadů byla stanovena doba od výkonu trestu žaláře. 5. Se shlazením byly spojeny účinky zákazu přihlížení k odsouzení a zákazu připomínání odsouzení pachateli, včetně jakýchkoli jiných negativních důsledků.

\section{Zahlazení odsouzení v letech 1918-1928}

Jako prováděcí zákon $\mathrm{k}$ zákonu o zločinech, přečinech a přestupcích byl na sklonku Rakousko-Uherské monarchie vydán zákon č. 108/1918 ř. z., o odčinění odsouzení (dále jen ,zákon o odčinění odsouzení“), který nabyl platnosti a účinnosti dne 21. března 1918. Následně byl tento zákon přejat Československou republikou a novelizován zákonem č. 208/1919 Sb. z. a n., kterým se mění odstavec 1. § 5 zákona z 21. března 1918, z. ř. č. 108, a doplňuje $\S 411$ tr. ř. (tato novela přinesla úpravu zejména „kosmetického“ charakteru, kdy nahradila slovo „císaře“ za slovo „prezident republiky“ atd.). Zákon o odčinění odsouzení, společně s jeho novelou, by zrušen zákonem č. 111/1928 Sb. z. a n., o zahlazení odsouzení.

Zákon o odčinění odsouzení obsahoval jak hmotněprávní, tak procesní ustanovení o postupu při zahlazování odsouzení (odčinění odsouzení). Obsahoval pouhých osm paragrafů a nebyl žádným způsobem členěn.

Odčinění se poskytovalo odsouzenému, který byl dříve soudně bezúhonný, odčinil škodu, kterou trestným činem způsobil a nebyl znovu odsouzen do uplynutí lhůty pro odčinění. Odčinění však nepřekáželo dřívější odsouzení za přestupek nebo přečin za předpokladu, že tento byl nepatrný nebo se nezakládal na úmyslu (,,bezectném smýšlení“). ${ }^{47}$ Zároveň s tím byla stanovena výjimka z odčinění, podle níž se neodčiňovaly zločiny, na něž byl stanoven trest odnětí svobody v délce více jak jeden rok. ${ }^{48} \mathrm{Z}$ tohoto pravidla byly vyloučeny př́pady, které upravovala novela (č. 131/1867 ř. z.) k zákonu o zločinech, přečinech a přestupcích v $\S 6$, mezi tyto náležely například nepřekažení, neoznámení zločinu velezrady, zločin rušení veřejného pokoje, mimo prrípady, kdy zmíněné zločiny směřovaly proti osobě císaře (dá se předpokládat, že v době republiky proti osobě prezidenta republiky); zločiny pozdvižení, vzbouření a násilného vztažení ruky na vrchnostenské osoby nebo jim nebezpečným vyhrožováním ve věcech veřejných za předpokladu, že tyto zločiny se zakládaly na politických motivech; zločiny veřejného násilí, souboje a nadržování.

47 § 1 odst. 2 zákona č. 108/1918 ř. z., o odčinění odsouzení (pozměněný zák. z 10. dubna 1919 Sb. z. a n. č. 208).

48 Na základě Recepčního zákona z pera A. Rašína byl na území Československa recipován právní řád Rakouska-Uherska a s tím i zákon o zločinech, přečinech a přestupcích (tento byl účinný až do roku 1950, kdy je nahrazen zákonem č. 86/1950 Sb., trestní zákon). Vzhledem k tomu taktéž zůstává rakousko-uherské rozdělení deliktů na zločiny přečiny a přestupky, kdy za zločiny jsou považovány závažnější delikty a je jim věnován první díl zákona, náleží mezi ně ,typická“ trestná činnost, např. vražda, loupež, krádež, vydírání, zneužití moci úřední atd. Za přečiny a přestupky byly považovány méně závažné delikty a byl jim věnován díl druhý zákona, jednotlivé přečiny a přestupky byly rozděleny do tří kategorií na přečiny a přestupky proti veřejné bezpečnosti, proti bezpečnosti jednotlivců a proti veřejné mravopočestnosti, náleželo mezi ně např. shluknutí, urážení církve nebo společnosti náboženské, zákonem uznané, z nečištění studnic, cisteren atd., krádeže mírnějšího druhu atd. 
Jak již bylo výše zmíněno, v recentní právní úpravě předchozí soudní bezúhonnost odsouzeného a bezpodmínečnost odčinění škody odsouzeným netvoří překážku zahlazení odsouzení. Neodsouzení za trestný čin v době nezbytné k zahlazení je podmínkou zahlazení i v současnosti. Nejednotnost soudního rozhodování je možné nalézt u přestupků, kdy lze obecně říci, že přestupek spáchaný v době nezbytné pro zahlazení by neměl zakládat překážku zahlazení, pokud se nejedná o přestupek na stejném úseku jako zahlazovaná trestná činnost. Zahladit je však možno jakékoliv odsouzení.

Lhůta k odčinění se počítala od vykonání trestu, případně od jeho prominutí milostít ${ }^{49}$ s tím, že se k této nepřipočítávala doba, po kterou byl odsouzený držen v ústavu, tj. lhůta byla stavěna $v$ případě, že byl odsouzený držen v trestním ústavu, trestnici, věznici, donucovací pracovně, polepšovně, ústavu pro choromyslné a jiných obdobných ústavech, z nichž chovanec tento smí opustit pouze v doprovodu dozorce..$^{50}$ Délka lhůty k odčinění se odvíjela od délky trestu odnětí svobody stanovené za příslušný čin a byla stanovena na patnáct let pro prŕípad zločinů (mimo zločiny zmíněné výše, tj. vypočtené v $\$ 6$ zákona č. 131/1867 ř. z.), deset let pro zločiny vypočtené v $\$ 6$ zákona č. 131/1867 ř. z., a pět let pro ostatní prípady.

Počátek běhu doby nezbytné k zahlazení odsouzení je v současné době stanoven na patnáct, deset, pět, tři a jeden rok dle druhu a výše uloženého trestu, přičemž jeho počátek je stanoven výkonem, promlčením nebo prominutím trestu. Nevedení rádného života vede $\mathrm{k}$,přetržení“ této doby a tato běží od znova. Zahladit odsouzení není možno dokud není vykonáno ochranné opatření (je-li opatření vykonáváno, doba se nestaví). ${ }^{51}$

Pro případy odčinění odsouzení zákonem neupravených mohl rozhodovat pouze císař, resp. později prezident republiky. ${ }^{52}$

Bylo-li odsouzení odčiněno, nastaly stejné účinky jako při současném zahlazení. Účinky zahlazení byly rozděleny na přímé a nepřímé. ${ }^{53}$ Mezi přímé účinky náležela skutečnost, že se na odsouzeného hledělo jako na osobu bezúhonnou (tj. za osobu nepotrestanou) za předpokladu, že pachatel neměl stále nějaká neodčiněná odsouzení. $\mathrm{S}$ bezúhonností byly spojeny další účinky, např. obnova způsobilosti k přísaze v právu procesním, nebo možnost nabytí živnosti (neobnovovala se však již na základě odsouzení

49 Na rozdíl od zákona č. 111/1928 Sb. z. a n., o zahlazení odsouzení, zákon o odčinění odsouzení se o promlčení výkonu trestu nezmiňuje. Důvodem zavedení podmínky počátku běhu lhůty nezbytné k zahlazení odsouzení spočívající v promlčení do zákona o zahlazení odsouzení bylo přijetí nařízení vlády republiky Československé č. 152/1920 Sb. z. a n., jímž se upravuje soudnictví a rozšiřuje působnost zákonů a nařízení z oboru soukromého práva a soudní správy v územích postoupených Československé republice podle mírových smluv, zejm. § 9 tohoto nařízení, které odkazovalo na §67-72 německého trestního zákona do té doby účinného na území Slovenska a Podkarpatské Rusi. Lze se tak domnívat (ač se autor pouští do pouhých spekulací, nebot' k této skutečnosti nenalezl podklady), že tímto odkazem, byla zavedena podmínka počátku běhu lhůt spočívající v promlčení od 1. 5. 1920, kdy nařízení nabylo účinnosti, i do zákona o odčinění odsouzení.

50 Obdobně též BALCAR, J. Zákon o zahlazení odsouzení. Kroměříž: Nakladatel J. Gusek, 1928, s. 35.

51 Srov. § 105 trestního zákoníku.

52 Pokud se jednalo o případ, který nebyl právně upraven, nebo o př́pad, že doposud nebyly splněny podmínky zahlazení, mohl prezident republiky užít svého postavení a zahladit odsouzení tím, že využil svého práva daného ústavní listinou (§ 103), resp. § 10 písm. f) prozatímní ústavy (z. č. 37/1918 Sb. z. a n.) a udělil milost.

53 Obdobně BALCAR, c. d., s. 42 a násl. 
pozbytá živnost, ale odpadala překážka jejího znovunabytí do budoucnosti). ${ }^{54}$ Nepř́mým účinkem odčinění bylo, že odsouzený své odsouzení ve styku se soudy a úřady nemusel vykazovat, tj. jednalo se tak o soudní bezúhonnost, která však nezbytně neznamenala nabytí tzv. občanské bezúhonnosti (úcty a vážnosti u spoluobčanů). ${ }^{55}$ Současně s tímto ale nebyla dotčena práva třetích osob, zakládajících se na základě odčiněného odsouzení 56 (nejednalo se však o odčinění škody, nebot' toto bylo podmínkou rozhodnutí o odčinění). Odčinění odsouzení se poznamenalo v trestním spisu, na trestním lístku trestního rejstříku úřadu ${ }^{57}$ a v záznamech správních úřadů. Takovéto odsouzení nesmělo být vykazováno na vyhotoveních trestního lístku, vysvědčení o bezúhonnosti nebo vykazováno jiným způsobem. Na druhou stranu tato skutečnost nebyla bezpodmínečná, např. v prŕípadě hodnocení věrohodnosti osoby svědka, použití zahlazeného odsouzení jako důkazu proti osobě spoluobviněné atd. ${ }^{58}$

Procesněprávní část zákona obsahovala ustanovení o př́íslušnosti soudu, osobách oprávněných k podání návrhu a o povinnostech státního zástupce. Věcně a místně příslušný byl vždy sborový soud, který rozhodl v I. stolici, př́ípadně též byl-li v jeho obvodu soud okresní, který rozhodl v I. stolici. Vždy tak o odčinění odsouzení rozhodoval soud na krajské úrovni (tj. sborový soud). Byl-li občan Československé republiky souzen v cizině, príslušnost soudu se odvíjela od jeho trvalého pobytu, prrípadně jeho posledního známého bydliště. Posledním případem byl ten, kdy nebyly splněny předešlé podmínky a o odsouzení rozhodl soud ve Vídni, příslušný k odčinění odsouzení tak byl zemský trestní soud v Praze, případně v Brně.

Recentní trestní řád ${ }^{59}$ upravuje př́íslušnost soudu odlišně a vytváří tak jisté obtíže. ${ }^{60}$ Věcně a místně př́islušný je okresní soud místa bydliště odsouzeného.

Povinností státního zástupce bylo prošetřit všechny skutečnosti, které zakládaly možnost soudu rozhodnout kladně o odčinění odsouzení, a to způsobem, který zasahoval do práv a cti odsouzeného nejmenším způsobem. Pro případy, že státní zástupce zjistil veškeré skutečnosti, aniž by bylo potřeba zvláštního šetření, byl povinen ex officio podat návrh na odčinění odsouzení.

54 Obdobně BALCAR, $c$. d., s. 46-47.

55 Obdobně BALCAR, c. d., s. 50.

56 Obdobně např. soukromoprávní nároky poškozeného, nároky spoludědiců při dědické nehodnosti, vydědění atd. srov. BALCAR, c. d., s. 56.

57 Moderní rejstř́iky trestů vznikají až na základě vládního nařízení č. 198/1922 Sb., o evidenci soudních provinilců a sbírání dat pro účely kriminální statistiky, které bylo přijato 14. července $1922 \mathrm{~s}$ účinností od 1. ledna 1923. Tento předpis upravoval jak organizaci rejstř́ku trestů (byl zrrízen u krajských státních zastupitelství a vnitřně rozdělen do oddílů A-C), tak jeho obsah (záznamy o trestních listech), funkci a činnosti (nakládání s došlými trestními listy, činnost trestní kanceláře a dohled státního zástupce, přeřazování trestních listů mezi jednotlivými odděleními rejstř́ku, úpravy ve stávajících trestních listech atd.). Avšak již před rokem 1923 lze nalézt pozitivní úpravu evidence soudně trestaných osob, a to dvorským dekretem č. 1818/1821 Sb. z. justičních a následně nařízením ministerstva spravedlnosti č. 44/1853 ř. z., přičemž tyto předpisy upravovaly vyplňování a nakládání s tabulkami obsahujícími údaje o odsouzených.

58 Obdobně BALCAR, $c$. d., s. 54-55.

59 Zákon č. 141/1961 Sb., o trestním řízení soudním (trestní řád), ve znění pozdějších předpisů. In: Sbírka zákonů: Česká republika. Praha: Ministerstvo vnitra, 1961, částka 66, s. 513-576 (dále jen „trestní řád“).

60 Srov. SKUPIN Z. J. Procesní podmínky zahlazeni odsouzeni. COFOLA 2018: Sborník z konference. Brno: Masarykova univerzita, 2018, s. 180-192. 
Současný trestní řád již nezakládá povinnost státního zástupce vše řádně prošetřit, avšak návrhové právo k zahájení rrízení o zahlazení odsouzení je mu zachováno (i když jen ve fakultativní podobě), obdobně tak právo k podání stížnosti.

Po vyslechnutí státního zástupce soud rozhodoval v neveřejném sezení (zasedání) usnesením. V případě, že nebyla škoda odsouzeným nahrazena, soud stanovil její výši a přiměřenou lhůtu k její náhradě. Proti usnesení bylo možno podat do tří dnů stížnost, která měla odkladný účinek.

Obdobným způsobem se nesl vládní návrh zákona o odčinění odsouzení vojenskými soudy, ${ }^{61}$ který přebíral z velké části znění zákona o odčinění odsouzení. Zákon měl směřovat, jak již název napovídá, k odčinění odsouzení vojenskými soudy, nebot' tyto odčiněny podle zákona o odčinění odsouzení být nemohly. Důvodová zpráva ${ }^{62}$ tak podává, že návrh zákona směřuje k tomu, aby osoby odsouzené vojenskými soudy byly postaveny na roveň osobám odsouzeným obecnými soudy. Návrh byl vypracován 7. června 1920, avšak nikdy nebyl prijat.

Ve zkoumaném období nelze opomenout zákon č. 562/1919 Sb. z. a n., o podmíněném odsouzení a podmíněném propuštění (dále jen „zákon o podmíněném odsouzení“), který byl účinný až do roku 1950, kdy byl zrušen zákonem č. 86/1950 Sb., trestní zákon. Zákon obsahoval jak ustanovení hmotněprávní, tak ustanovení procesní, byl členěn na dvě části, a to na část o podmíněném odsouzení a na část o podmíněném propuštění.

Soud mohl podmíněně odložit výkon peněžitého trestu nebo trestu odnětí svobody, který nepřesahoval dobu jednoho roku (do doby jednoho roku se včítala délka náhradního trestu ukládaného pro př́pady nevykonání peněžitého trestu), na zkušební dobu jednoho až tří let, byl-li uložen peněžitý trest nebo trest odnětí svobody do šesti měsíců, a dvou až pěti let, byl-li uložen trest odnětí svobody delší šesti měsíců (nejdéle však na jeden rok). Zároveň zákon stanovoval negativní podmínky v $§ 2$ zákona o podmíněném odsouzení, mezi něž náleželo předchozí odsouzení na dobu delší tří měsíců odnětí svobody nebo čin spáchaný z pohnutky „nízké a nečestné“ (dnes by se tato pohnutka dala pravděpodobně vykládat dle ustanovení $\S 42$ písm. b) trestního zákoníku ${ }^{63}$ ). Z tohoto byly vymezeny výjimky, mezi něž náleželo promlčení, osvědčení se ve zkušební době a uplynutí doby pěti let od právní moci prominutí trestu za přečin nebo přestupek. Lze se domnívat, ač zákon o podmíněném odsouzení tak výslovně neuvádí, že mezi tyto výjimky bylo možno zařadit i odčinění odsouzení podle zákona o odčinění odsouzení, a to vzhledem k účinkům, jež byly odčiněním odsouzení vyvolány (viz výše).

Recentní úprava podmíněného odkladu výkonu trestu odnětí svobody je obsažena v trestním zákoníku, není jí tudíž věnován vlastní zákon. Podmínky odkladu výkonu jsou upraveny výrazně mírněji, kdy soud může takto učinit, ukládá-li trest odnětí svobody ve výši až na tři roky, přičemž současně uloží zkušební dobu až na pět let. Tímto zmírněním podmínek jsou vtěleny základní myšlenky moderního trestního práva, zejm. důraz

\footnotetext{
61 Srov. Vládní návrh zákona ze dne ... 1920, o odčinění odsouzení vojenskými soudy, Poslanecká sněmovna, Národní shromáždění republiky Československé 1920-1925, I. Volební období, 1. zasedání, Tisk č. 32, dostupné na: http://www.psp.cz/eknih/1920ns/ps/tisky/index01.htm.

62 Tamtéž.

63 „... spáchal trestný čin ze ziskuchtivosti, z pomsty, z národnostní, rasové, etnické, náboženské, tř̌ídní či jiné podobné nenávisti nebo z jiné zvlášt' zavrženíhodné pohnutky...““
} 
na restorativní principy, přihlédnutí k subsidiaritě trestní represe aj. Na druhou stranu výkon peněžitého trestu nelze podmíněně odložit dospělému pachateli, soud může takto učinit pouze u pachatelů mladistvých. ${ }^{64}$

Ve zkušební době podmíněného odsouzení byl odsouzený povinen příslušné odsouzení uvádět pouze na dotaz soudu. Stejně jako dnes, osvědčil-li se odsouzený v době podmíněného odsouzení, mělo se za to, že nebyl odsouzen [odsouzení bylo odčiněno ex decreto (o osvědčení rozhodoval soud; obdobně je tomu i dnes), stejně jako v případě odčinění podle zákona o odčinění odsouzení]. V opačném případě soud nařídil výkon odloženého trestu. Podmínky, za nichž soud nařídil výkon podmíněně odloženého trestu, byly velmi přísné, náleželo mezi ně např. nesplnění podmínek uvedených v $§ 2$ zákona o podmíněném odsouzení, oddával-li se odsouzený v době podmíněného odsouzení nezřízenému pití alkoholických nápojů, hráčství, zahálčivému životu nebo životu nemravnému, přes napomenutí odmítal odčinit škodu nebo byl odsouzen pro jiný zločin atd.

Př́ípady odčinění odsouzení podmíněného propuštění zákon o podmíněném odsouzení neupravoval. Tudíž odčinění nebylo možné, a to vůbec, nebot' jak plyne ze zákona o odčinění odsouzení, bylo možno odčinit pouze zločin, za nějž byl stanoven trest do jednoho roku odnětí svobody. Při pohledu do ustanovení § 10 zákona o podmíněném odsouzení jasně plyne, že podmíněně propuštěn mohl být pouze pachatel, který byl odsouzen k trestu delšímu jednoho roku, z něhož již vykonal alespoň dvě třetiny, nejméně však jeden rok. Proto nebylo možno takový trest odčinit.

Ze zákona o odčinění odsouzení je jasné, že se postupně blíží k podobě současné úpravy, avšak plyne z něj ještě významná přísnost, zejména při pohledu na podmínky odčinění odsouzení, které vylučovaly odčinění odsouzení, na nějž byl stanoven trest odnětí svobody v délce nad jeden rok. Na druhou stranu lze zajisté ocenit skutečnost, že odsouzení mohlo být odčiněno až poté, co pachatel odčinil škodu jím způsobenou, což bezpochyby vyvíjelo tlak na odsouzeného, na druhou stranu tato skutečnost mohla také odsouzenému bránit v nabytí práce, příp. povolání, a následné možnosti odčinit př́ípadnou majetkovou škodu. Avšak bezpochyby tato skutečnost velmi zvýhodňovala a zesilovala postavení poškozeného vůči odsouzenému. Nelze opomenout úpravu místní a věcné příslušnosti soudu, která byla vázána na místo soudu, který rozhodoval o meritu věci.

Úprava zahlazení podmíněného odsouzení se shoduje se současnou úpravou zahlazení, rozdílnost je však možno spatřovat ve velmi přísně nastavených podmínkách osvědčení se zákonem o podmíněném odsouzení. Zároveň výrazný rozdíl lze nalézt i v oblasti podmíněného propuštění, kdy toto nebylo možno zahladit vůbec, což se z dnešního pohledu jeví taktéž nepřiměřeně př́isné.

Pro shrnutí, období od roku 1918-1928 se vyznačovalo následujícím: 1. Př́ínými podmínkami a relativně úzkým okruhem trestných činů, které mohly být odčiněny (tj. zahlazeny). 2. Odsouzení mohlo být odčiněno po uplynutí lhůty, jejíž délka se odvíjela od délky trestu odnětí svobody a počínala svůj běh výkonem tohoto trestu nebo udělením milosti. 3. Bylo-li odsouzení odčiněno, na pachatele se hledělo jako na osobu (soudně) bezúhonnou.

64 Srov. § 28 a násl. zákon č. 218/2003 Sb., o odpovědnosti mládeže za protiprávní činy a o soudnictví ve věcech mládeže a o změně některých zákonů (zákon o soudnictví ve věcech mládeže), ve znění pozdějších předpisů. In: Sbirka zákonů: Česká republika. Praha: Ministerstvo vnitra, 2003, částka 79, s. 4030-4052. 
4. O odčinění rozhodoval vždy soud, státní zástupce měl v rozhodování o odčinění řadu povinností. 5. Osvědčením ve zkušební době podmíněného odsouzení nastávaly účinky odčinění.

\section{Závěr}

Bezpochyby lze konstatovat, že v trestním řízení dlouhou dobu přetrvávaly velmi kruté praktiky. Proto v mnoha př́padech institutu zahlazení nebylo třeba, nebot' osoba, proti níž se trestní řízení vedlo, toto řízení nepřežila, nebo následně na ní byl vykonán trest smrti; ve druhém př́padě zahlazení nebylo účelné, respektive funkční, nebot' např. na osobě byl vykonán tělesný trest formou cejchu nebo jiného značení a zahlazení by tak bylo kontraproduktivní. Jistou změnu přináší doba osvícenská a trestní zákoník Marie Terezie, ač i tento stále obsahoval torturu, je možné se setkat s jistou formou zahlazení. Nepochybně výrazným krokem v oblasti zahlazení odsouzení bylo vydání trestního zákoníku Josefa II., který obsahoval již plnohodnotná ustanovení o zahlazení odsouzení. Vývoj byl dovršen vydáním trestního zákoníku o zločinech, přečinech a proviněních z roku 1852.

Ve srovnání se současnou úpravou lze vyslovit názor, že úprava zahlazení v době habsburského soustátí od roku 1852 byla z jednoho pohledu mírnější pro prrípady zahlazení všech trestných činů ex lege po jejich výkonu, z druhého pohledu výrazně přísnější, pro př́pady absolutní nemožnosti nabýt ztracené tituly, vyznamenání nebo úřady (před novelou). Př́íslušná novela stanovila zkušební dobu pro možnost nabytí titulů, vyznamenání nebo úřadů, a tím se výrazným způsobem přiblížila současné úpravě. S nadsázkou lze říci, že tato úprava působila obdobným způsobem, jako například dnešní přikládání výpisu $\mathrm{z}$ rejstříku trestů u přihlášek k výběrovému řízení do veřejných úřadů, u nichž je žádána bezúhonnost, nebot' trest byl zahlazen automaticky jeho výkonem, avšak zůstal zákaz výkonu veřejných úřadů po určitou dobu od vykonání trestu.

Prvním zákonem, který byl vyhrazen výlučně zahlazení odsouzení, byl zákon o odčinění odsouzení z roku 1918. Ve srovnání se současnou právní úpravou byla úprava zákona o odčinění výrazně př́ísnější, nebot' nebylo možno odčinit odsouzení, v nichž byl uložen trest odnětí svobody převyšující jeden rok. Oproti tomu se všechna odsouzení shlazovala ex lege, odsouzený tak nemusel podávat žádnou žádost.

Současná úprava institutu zahlazení odsouzení není bezchybná a vykazuje řadu nedostatků, závěrem lze ale vyslovit myšlenku, že je možné si z historické podoby jistě vzít inspiraci a při návrzích nové úpravy de lege ferenda přihlédnout i k podobám, které institut vykazoval od roku 1852 do roku 1928. 